\title{
Perancangan Alat Pelacak Lokasi Dalam Mengantisipasi Penculikan Anak
}

\author{
Engineering of Location Tracking Devices for Anticipating Child Abduction \\ Zulfikar Sembiring*1, Rizki Muliono ${ }^{2}$ \\ ${ }^{1,2}$ Universitas Medan Area; Jalan Kolam No.1 Medan Estate, (061) 7366878 \\ ${ }^{3}$ Jurusan Teknik Informatika, FT UMA, Medan \\ e-mail: *1 zulfikarsembiring@ ${ }^{2 t a f f . u m a . a c . i d, ~}{ }^{2}$ rizkimuliono@staff.uma.ac.id
}

\begin{abstract}
Abstrak
Kasus penculikan anak selalu meningkat dari tahun ke tahun berdasarkan sumber dari Komisi Perlindungan Anak Indonesia (KPAI). Kasus ini juga pernah menjadi isu nasional di beberapa media masa. Banyak sekali faktor penyebab kasus ini bisa terjadi. Selain itu beberapa cara pencegahan telah disarankan dan digunakan dalam mengantisipasi terjadinya tindakan penculikan anak. Namun dari beberapa cara pencegahan yang telah disarankan masih terkendala oleh jarak dan waktu. Salah satunya bagaimana orang tua dapat memantau posisi lokasi anak pada satu waktu tertentu. Hal ini pasti sangat sulit dilakukan kalau tanpa menggunakan teknologi. Oleh karena itu penulis tertarik melakukan penelitian untuk menghasilkan satu rancangan alat pelacak lokasi anak yang dapat mengantisipasi penculikan anak. Alat pelacak lokasi ini dirancang dengan menggunakan beberapa komponen yaitu arduino, GPS dan GPRS modul, SIM card, smartphone android dan aplikasi google maps yang dirancang sedemikian rupa menjadi alat pelacak yang dapat memberikan informasi lokasi. Informasi lokasi ini dapat dilihat oleh orang tua melalui perangkat smartphone android dengan aplikasi google maps. Sehingga orang tua dapat memantau kapan saja lokasi anak mereka dengan mudah sehingga dapat menghemat waktu, jarak dan biaya. Ada beberapa tahapan yang digunakan untuk menghasilkan alat pelacak lokasi ini dapat bekerja dengan baik yaitu persiapan perangkat keras dan lunak yang dibutuhkan, perancangan rangkaian perangkat keras, pembuatan kode program sesuai rancangan rangkaian dan pengujian perangkat keras dan lunak. Hasil akhir dari penelitian alat pelacak lokasi ini yaitu menghasilkan informasi lokasi yang akurat, aplikasi yang sangat mudah digunakan serta komponen perangkat keras dan perangkat lunak dapat berjalan dengan baik.
\end{abstract}

Kata kunci-Alat Pelacak, lokasi, Arduino, GPS

\begin{abstract}
Child abduction cases always increase from year to year based on sources from the Indonesian Child Protection Commission (KPAI). This case has also been a national issue in several mass media. There are many factors that can cause this case. In addition, several ways of prevention have been suggested and used in anticipation of child abduction. However, from a number of ways the prevention that has been suggested is still constrained by distance and time. One of them is how parents can monitor the location of a child's location at a certain time. This is definitely very difficult to do without using technology. Therefore the authors are interested in conducting research to produce a design of a location tracking device for children who can anticipate child abduction. This location tracking device is designed using several components namely arduino, GPS and GPRS module, SIM card, android smartphone and google maps application which is designed in such a way as a tracking device that can provide location information. This location information can be seen by parents via the Android smartphone device with the Google Maps application. So that parents can monitor their child's location easily so that they can save time, distance and costs. There are several steps that are used to
\end{abstract}


produce this location tracking device that can work well, namely the hardware and software preparation needed, the design of hardware circuits, the creation of program codes according to the circuit design and hardware and software testing. The end result of this location tracking device research is to produce accurate location information, applications that are very easy to use and hardware and software components can run well.

Keywords—Tracking Tool, location, Arduino, GPS

\section{PENDAHULUAN}

Kasus penculikan anak semakin marak sekarang ini. Kasus ini dari tahun ke tahun selalu meningkat. Banyak sumber berita nasional maupun daerah baik di media televisi, cetak maupun online yang menyajikan kasus ini sebagai berita utama. Bahkan pada tahun 2016 dan 2017 kasus ini menjadi isu nasional oleh Komisi Perlindungan Anak Indonesia (KPAI) [1]. Ada beberapa faktor yang menyebabkan kasus penculikan anak bisa terjadi, antara lain sikap dan pribadi anak yang masih polos sehingga tidak dapat melakukan perlindungan diri sendiri, kurangnya tingkat pengawasan orang tua terhadap anak di luar rumah misalnya di sekolah, terbatasnya pengawasan guru dan sekolah terhadap anak didiknya di luar sekolah. Sehingga terdapat celah atau kesempatan yang bisa dimanfaatkan oknum-oknum tertentu untuk melakukan tindak kejahatan misalnya penculikan.

Beberapa tindakan pencegahan sudah diberikan kepada orang tua dan anak mereka. Pihak-pihak berwenang seperti kepolisian, KPAI, pakar psikologi anak, dan guru banyak ikut serta dalam tindakan pencegahan ini. Namun itu semua masih dalam aspek psikologis dan ruang lingkup yang terbatas. Di sisi lain misalnya penggunaan teknologi, pada dasarnya bisa dimanfaatkan sebagai alat monitoring anak dalam mengantisipasi tindakan penculikan. Karena di era teknologi informasi sekarang ini produk-produk seperti smart phone, smart watch dan gadget lainnya tidak terlepas dari anak itu sendiri. Terlebih lagi teknologi memiliki keunggulan dalam aspek ruang dan waktu. Akan tetapi pada beberapa kasus tertentu misalnya perampokan pada anak, barang-barang berharga misalnya smart phone, smart watch dan gadget lainnya menjadi incaran dari pelaku tindak kejahatan itu terjadi. Berdasarkan paparan rinci tersebut maka peneliti tertarik untuk merancang satu alat pelacak lokasi yang dapat digunakan untuk mengantisipasi tindakan penculikan anak.

Dalam penelitian ini penulis melakukan beberapa studi literatur dari penelitian terdahulu yang relevan dengan perancangan alat pelacak lokasi. Berbicara tentang pengolahan data dan informasi lokasi berbasiskan teknologi sekarang ini tidak lepas dari GPS (Global Positioning System). Hampir semua alat transportasi yang canggih sekarang ini baik di darat, laut dan udara telah menggunakan GPS. Tidak hanya itu, beberapa merek gadget canggih juga sudah tertanam komponen GPS didalamnya. Beberapa penelitian terdahulu yang menggunakan konsep GPS antara lain pemanfaatan GPS dalam mendapatkan waktu universal [2], pemanfaatan data lokasi berbasis GPS dalam bentuk data log [3], pemanfaatan GPS pada jarak dan waktu kereta api [4], alat pendeteksi otomatis pencurian pada pengangkut BBM [5]. Dari semua hasil penelitian tersebut bahwa GPS dapat memberikan informasi lokasi yang akurat.

Selain penggunaan GPS, penelitian ini juga menggunakan komponen mikrokontroler sebagai pusat pemrosesan data dan informasi. Mikrokontroler digunakan karena lebih praktis dalam perancangan dan biaya yang murah. Mikrokontroler yang digunakan yaitu open source platform arduino. Beberapa penelitian terdahulu yang menggunakan arduino sebagai referensi penulis yaitu pemanfaatan arduino dalam pengolahan jumlah ban di gudang [6], perancangan dan pengembangan sistem monitoring kebocoran gas [7], simulasi membaca dan mengirim data melalui protokol HTTP [8], pemanfaatan arduino dalam sistem irigasi tetes otomatis berbasis perubahan kadar air tanah [9], sistem akuisisi data iklim mikro dalam greenhouse [10] dan rancang bangun sistem prabayar pada PDAM [11]. 


\section{METODE PENELITIAN}

Beberapa metode penelitian yang digunakan pada penelitian ini dapat dilihat pada gambar berikut ini.

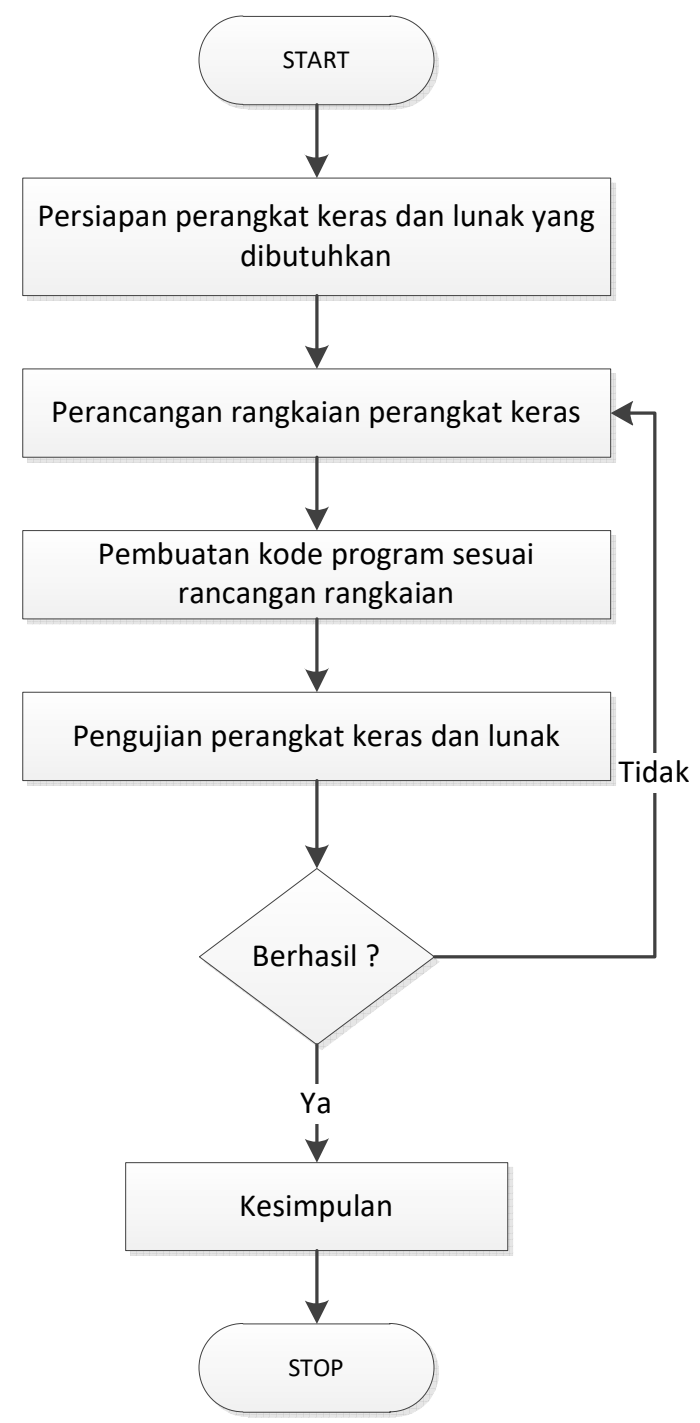

Gambar 1 Tahapan Penelitian

2.1 Persiapan Perangkat Keras dan Lunak Yang Dibutuhkan

Berikut ini beberapa komponen yang digunakan pada penelitian, antara lain :

1) Arduino Uno R3 : Komponen ini digunakan sebagai pusat pengontrolan yang dapat dintegrasikan dengan komponen yang lain selain itu dapat diprogram secara fleksibel sesuai kebutuhan programmer. 


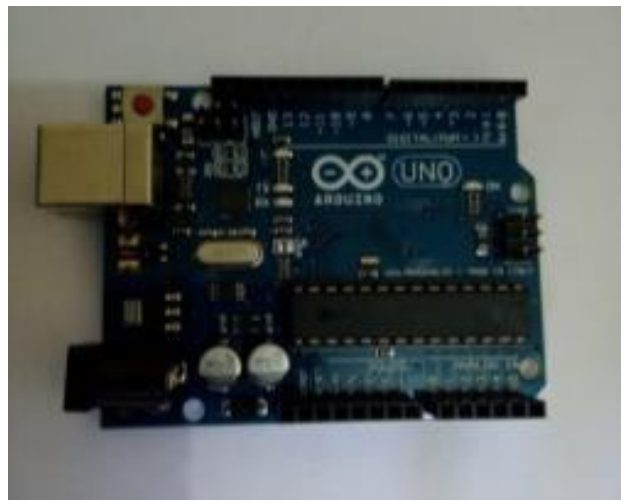

Gambar 2 Arduino Uno R3

2) Modul SIM808 EVB V3.2 : Komponen ini digunakan sebagai modul GSM / GPRS QuadBand yang lengkap dengan menggabungkan teknologi GPS untuk navigasi satelit. Memiliki desain ringkas yang mengintegrasikan GPRS dan GPS dalam paket SMT yang dapat menghemat waktu dan biaya bagi pengguna dalam mengembangkan aplikasi berbasiskan GPS. Serta dapat digunakan secara fleksibel sebagai alat pelacak di setiap lokasi dan kapan saja dengan jangkauan sinyal yang luas.

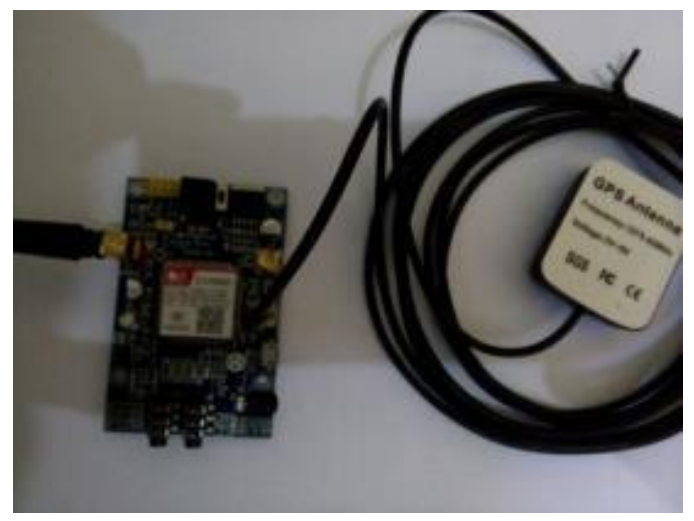

Gambar 3 Modul SIM808 EVB V3.2

3) Kartu SIM : digunakan untuk provider komunikasi GPRS/GSM.

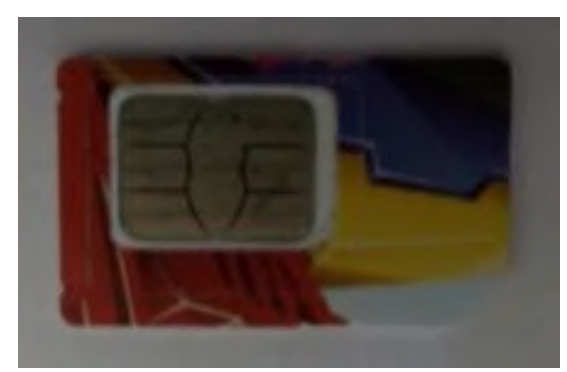

Gambar 4 Kartu SIM 
4) Sumber arus : komponen ini dapat menggunakan batere atau adaptor.

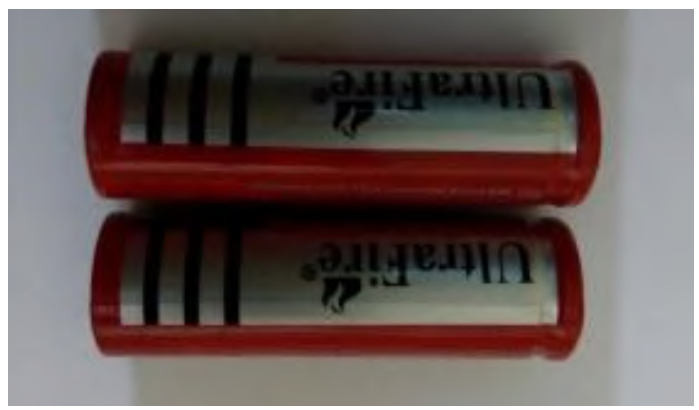

Gambar 5 Baterai

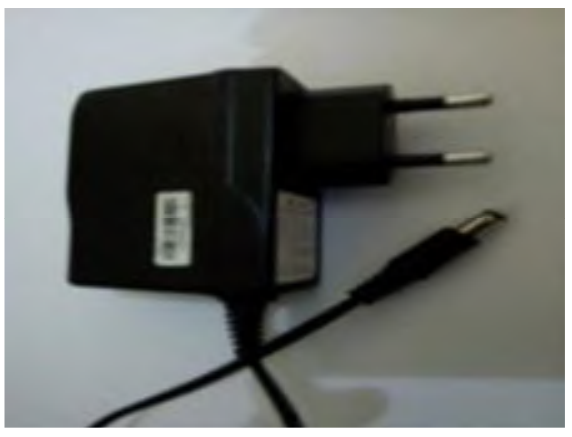

Gambar 6 Adaptor

5) Kabel jumper : komponen ini sebagai konektor antara beberapa komponen

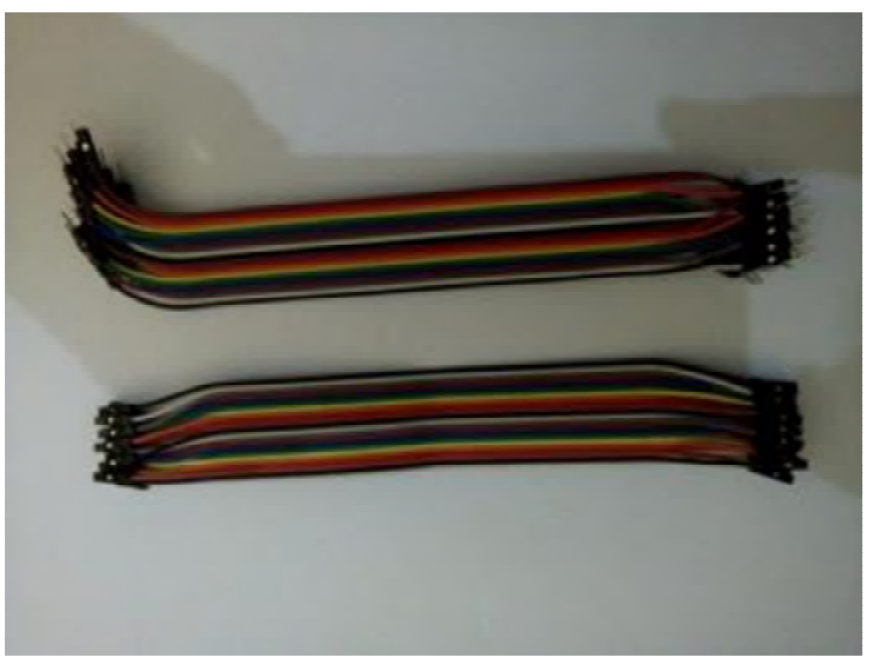

Gambar 7 Kabel Jumper

\subsection{Perancangan Rangkaian Perangkat Keras}

Semua komponen yang telah diuraikan sebelumnya kemudian dirangkai menjadi satu rangkain menjadi satu rangkaian alat pelacak lokasi seperti gambar berikut ini. 


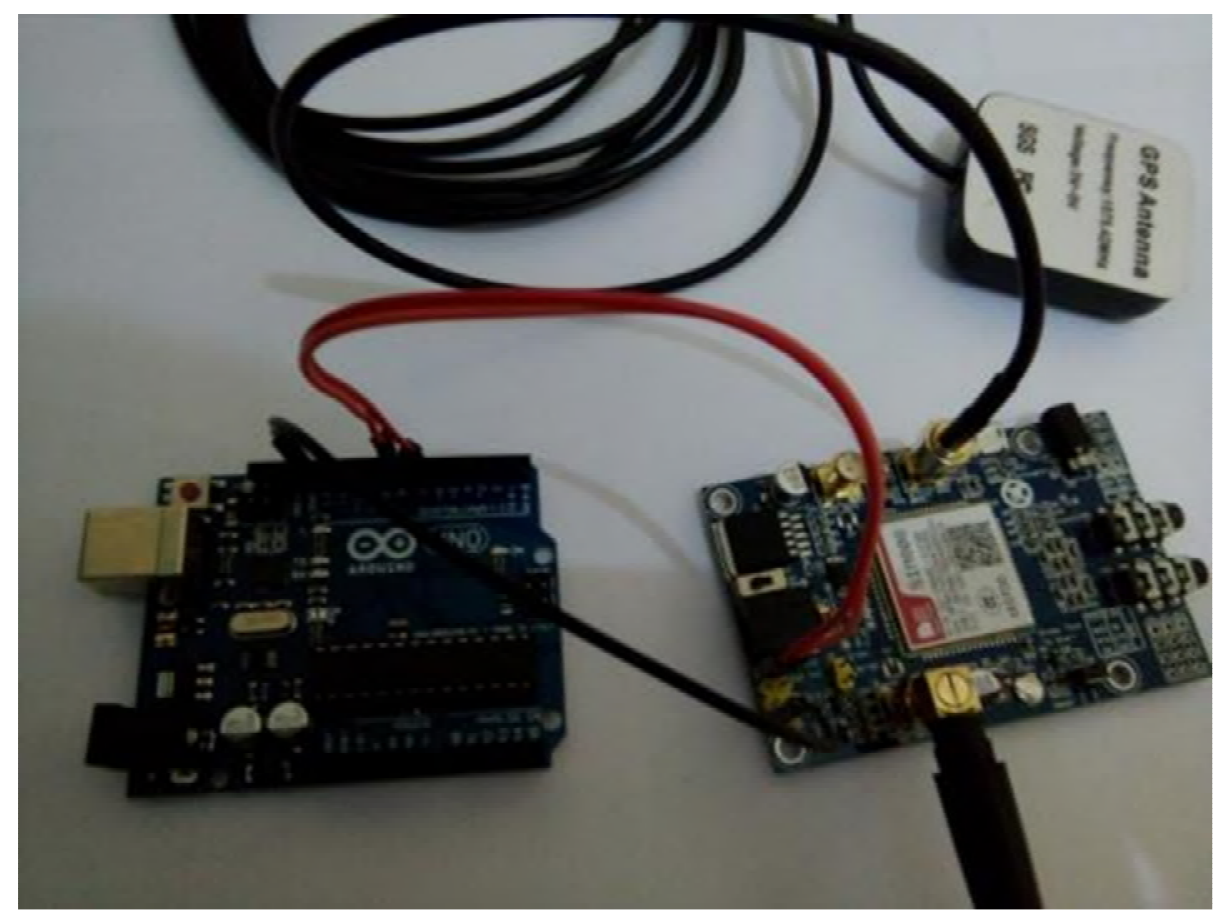

Gambar 8 Rancangan Rangkaian

\subsection{Pembuatan Kode Program}

Pada tahapan ini pembuatan kode program ke dalam arduino studio dengan kode program sebagai berikut :

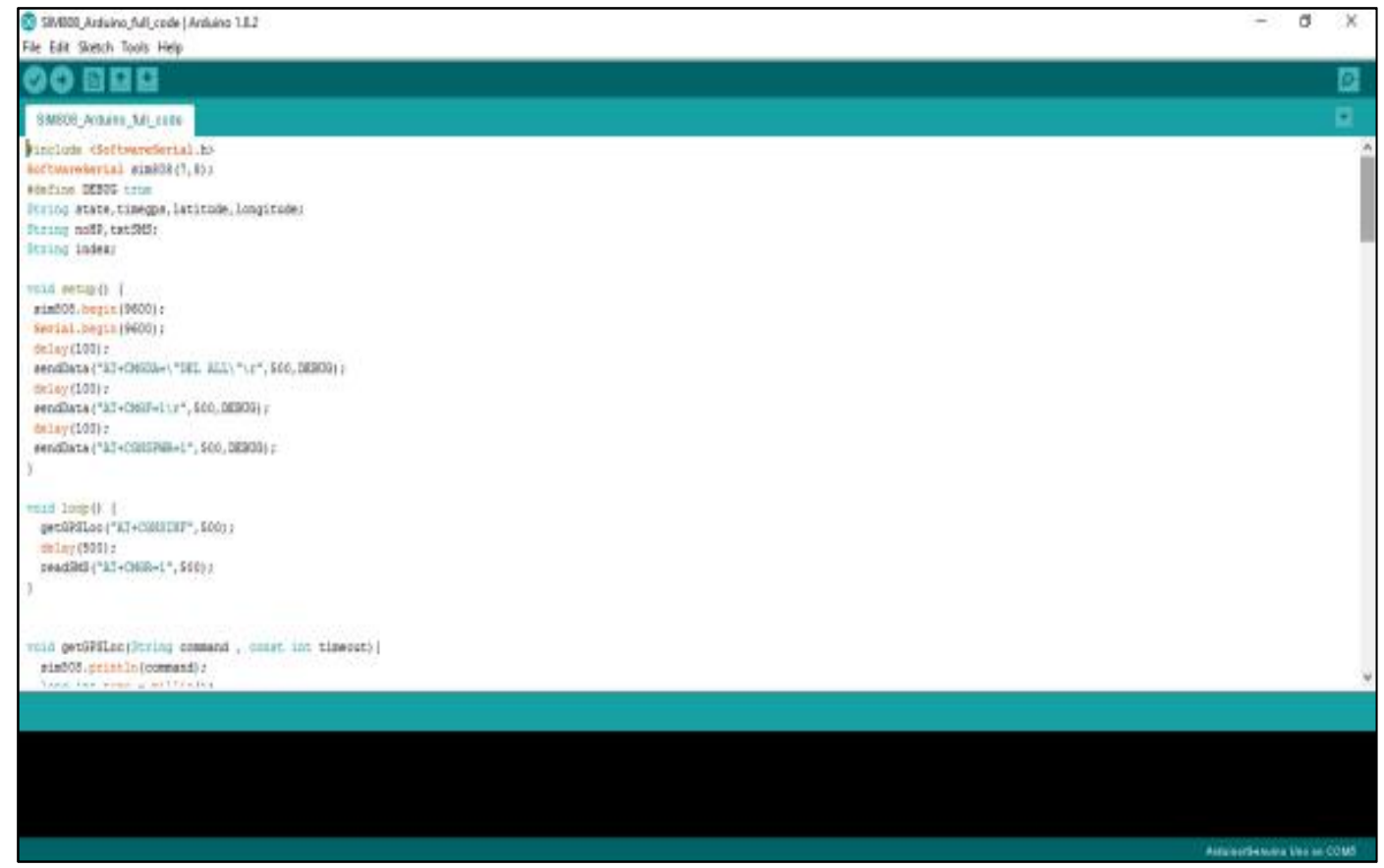

Gambar 9 Kode Program Pada Arduino Studio 
2.4 Pengujian Perangkat Keras Dan Lunak

Berikut ini beberapa tampilan hasil pengujian perangkat lunak dan perangkat keras, sebagai berikut :

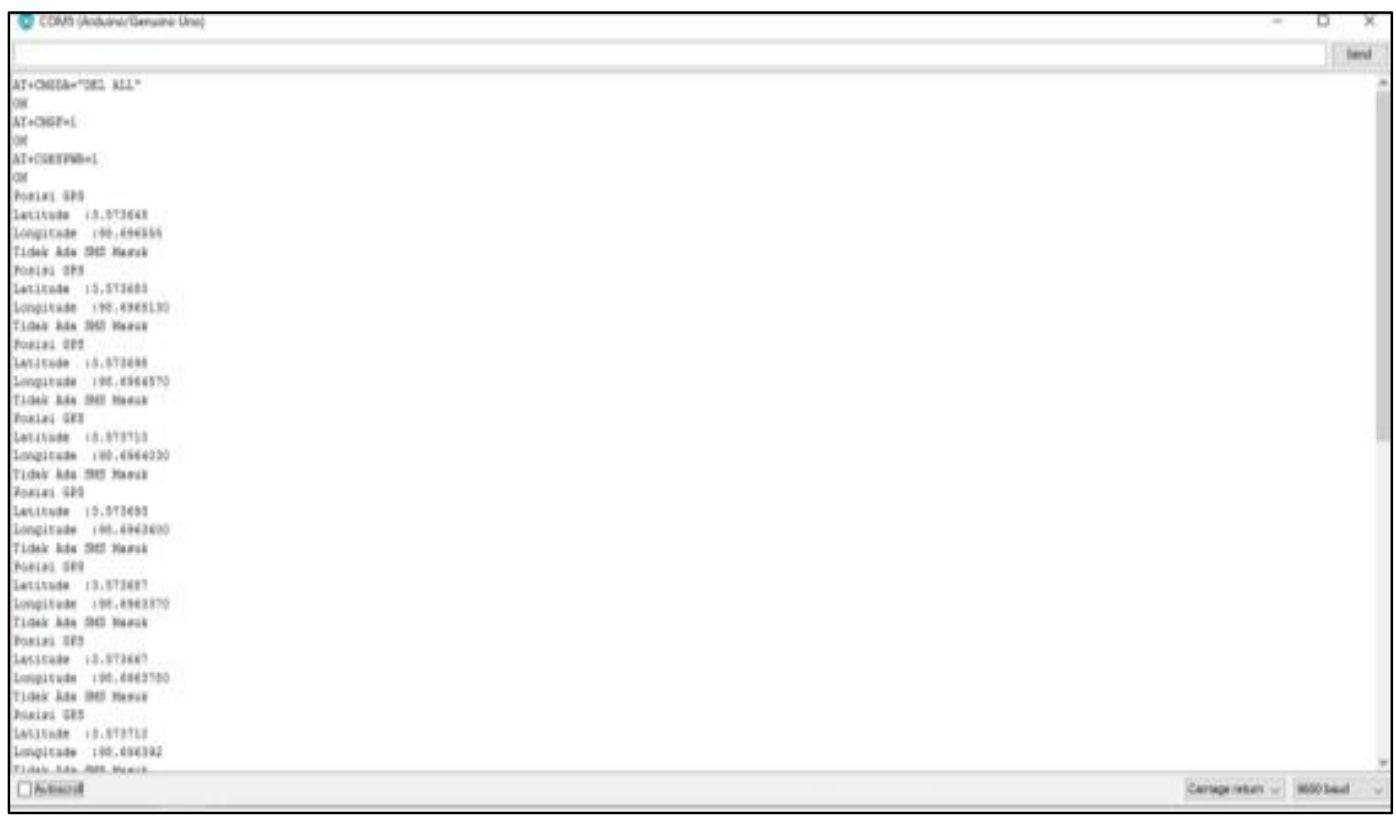

Gambar 10 Tampilan Inisialisasi Awal Pengujian Perangkat Keras

Pada gambar 10 merupakan tampilan serial terminal dari arduino studio yang menampilkan berjalannya rancangan rangkaian perangkat keras dan perangkat lunak dengan baik tanpa ada menampilkan pesan kesalahan.

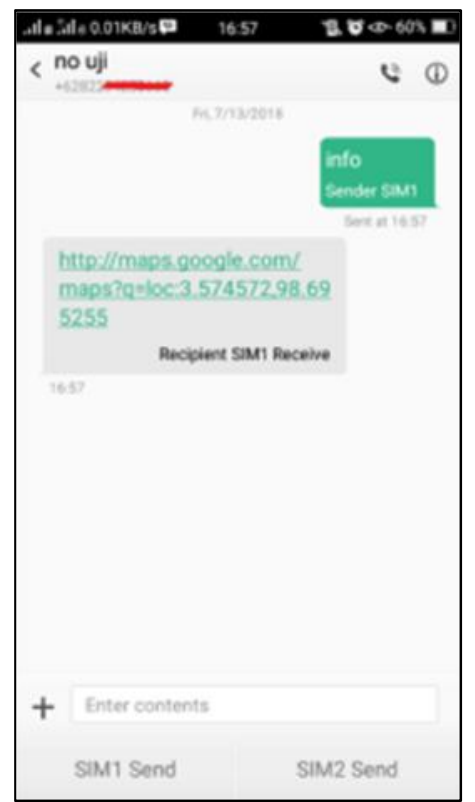

Gambar 11 Tampilan Pengiriman Pesan SMS Dengan Format Yang Benar Dan Balasan Pesan SMS Yang Benar Dari Alat Pelacak 
Pada gambar 11 merupakan tampilan pengiriman pesan SMS dari smartphone ke alat pelacak dengan format pesan teks yang benar yaitu "info". Kemudian alat pelacak mengirim balasan SMS sebagai informasi lokasi GPS berupa posisi latitude dan longitude kedalam pesan teks dengan format "http://maps.google.com/maps?q=loc:x.xxxxxx,y.yyyyyy". Selain itu dapat dilihat pada serial terminal arduino studio bahwa terdapat SMS masuk ke dalam alat pelacak seperti gambar 12 .

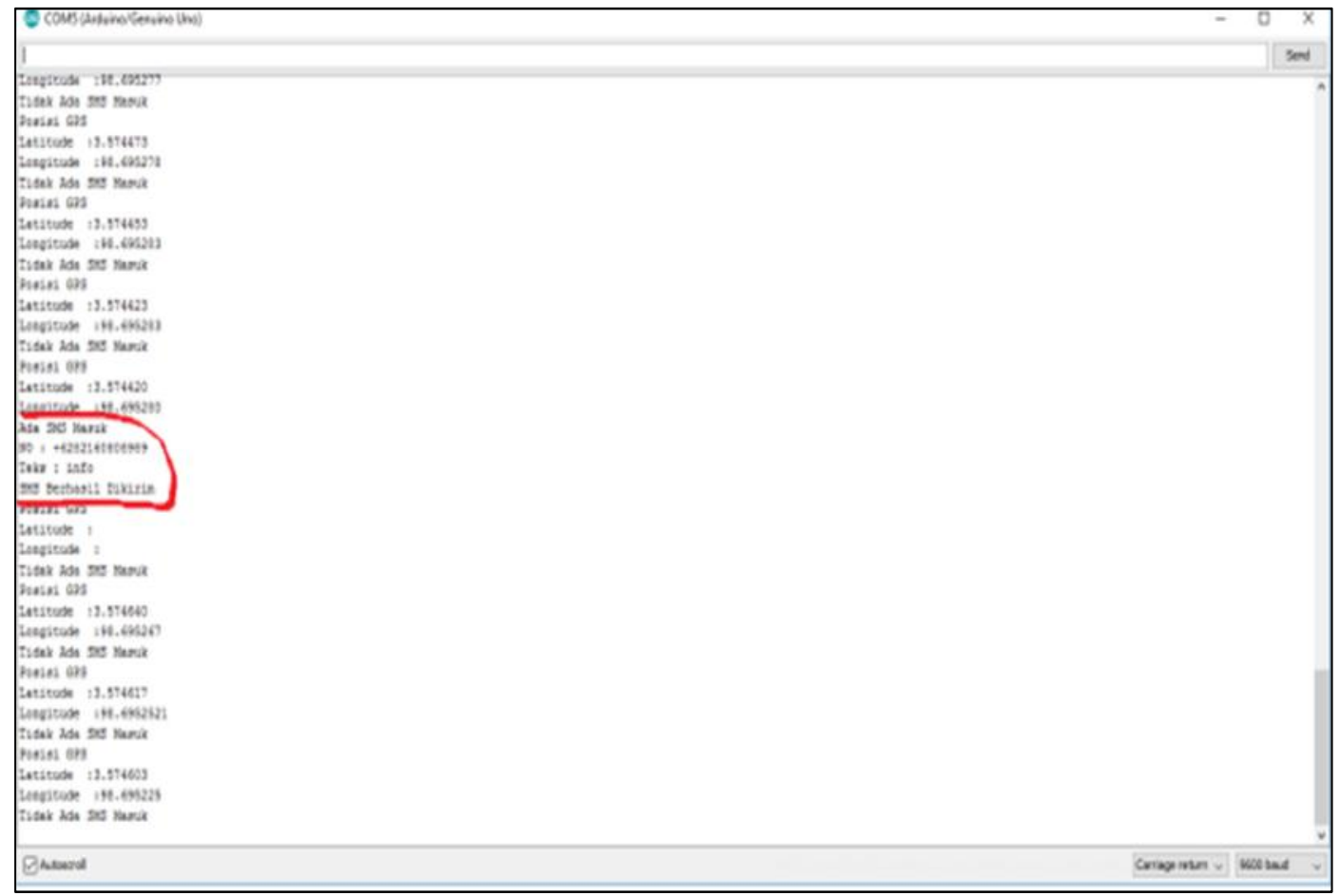

Gambar 12 Tampilan SMS Masuk Ke Alat Pelacak

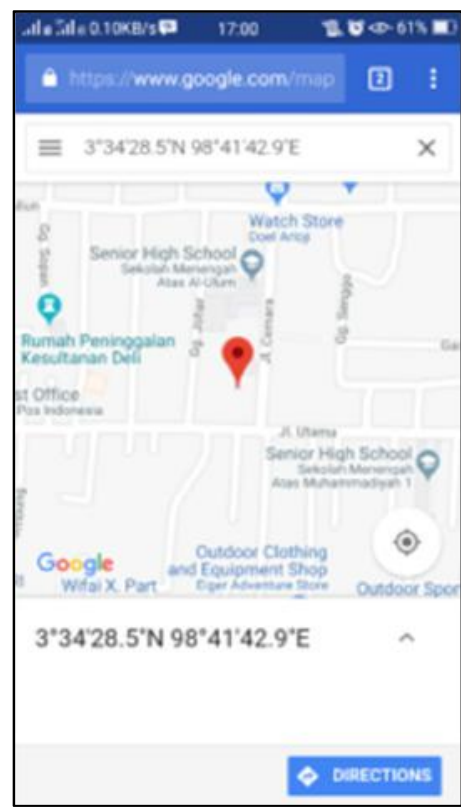

Gambar 13 Tampilan Hasil Lokasi Pelacakan dengan Google Map 
Pada gambar 13 ditampilkan hasil lokasi pelacakan dengan google map yang dikirim sesuai format SMS yang benar melalui smartphone. Sedangkan pada gambar 14 merupakan tampilan pengujian pengiriman SMS dengan format yang salah serta pengiriman pesan SMS yang salah dari alat pelacak.

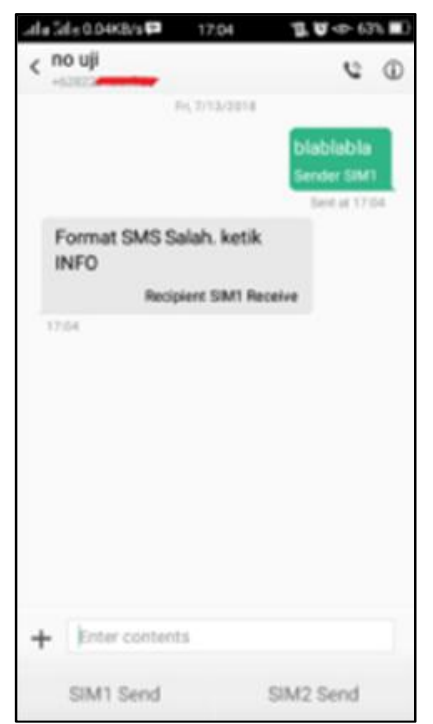

Gambar 14 Tampilan Pengiriman Pesan SMS Dengan Format Yang Salah Dan Balasan Pesan SMS Yang Salah Dari Alat Pelacak

\section{HASIL DAN PEMBAHASAN}

Pada bab ini diuraikan hasil pengujian dari perancangan alat pelacak lokasi dengan menyesuaian pada waktu mulai dan selesai kegiatan sekolah anak. Kemudian, Ada dua bagian penting dari penggunaan alat pelacak lokasi ini. Pertama pemantau, yaitu orang tua yang menggunakan smartphone android melakukan pemantauan lokasi anak. Sedangkan yang kedua yaitu anak yang membawa alat pelacak lokasi yang telah ditempatkan di dalam tas sekolah. Pemantauan lokasi dilakukan berdasarkan waktu kegiatan sekolah yaitu 08:00 - 14:00 WIB dengan asumsi bahwa anak masih berada di dalam lingkungan sekolah. Setelah itu pemantauan lokasi pada waktu diatas 14:00 WIB dengan asumsi bahwa anak berada diluar lingkungan sekolah dan akan menuju rumahnya. Durasi pengujian alat pelacak dilakukan setiap satu jam sekali baik pada waktu 08:00 - 14:00 WIB dan 30 menit sekali pada waktu diatas 14:00 WIB.

Berikut ini dapat dilihat hasil pengujian pada waktu 08:00 - 14:00 WIB dengan asumsi bahwa anak masih berada di dalam lingkungan sekolah.

Tabel 1 Hasil Pengujian Pada Waktu 08:00 - 14:00 WIB

\begin{tabular}{|c|c|c|c|}
\hline $\begin{array}{c}\text { No. } \\
\text { pengujian }\end{array}$ & $\begin{array}{c}\text { Waktu (dalam } \\
\text { WIB) }\end{array}$ & $\begin{array}{c}\text { Data lokasi yang diperoleh } \\
\text { dari alat pelacak (latitude, } \\
\text { longitude) }\end{array}$ & $\begin{array}{c}\text { Keterangan (apakah lokasi anak } \\
\text { masih di dalam lingkungan sekolah } \\
\text { ? ya/tidak) }\end{array}$ \\
\hline 1 & $08: 00-09: 00$ & $3.575322,98.695402$ & Ya \\
\hline 2 & $09: 00-10: 00$ & $3.575336,98.695361$ & Ya \\
\hline 3 & $10: 00-11: 00$ & $3.575322,98.695348$ & Ya \\
\hline 4 & $11: 00-12: 00$ & $3.575379,98.695408$ & Ya \\
\hline 5 & $12: 00-13: 00$ & $3.575308,98.695358$ & Ya \\
\hline 6 & $13: 00-14: 00$ & $3.575340,98.695361$ & Ya \\
\hline
\end{tabular}


Dari data latitude dan longitude pada tabel 1 diatas jika dimasukkan kedalam aplikasi google maps maka akan tampak bahwa posisi anak masih dalam lokasi di dalam lingkungan sekolah. Seperti pada kumpulan beberapa gambar berikut ini.

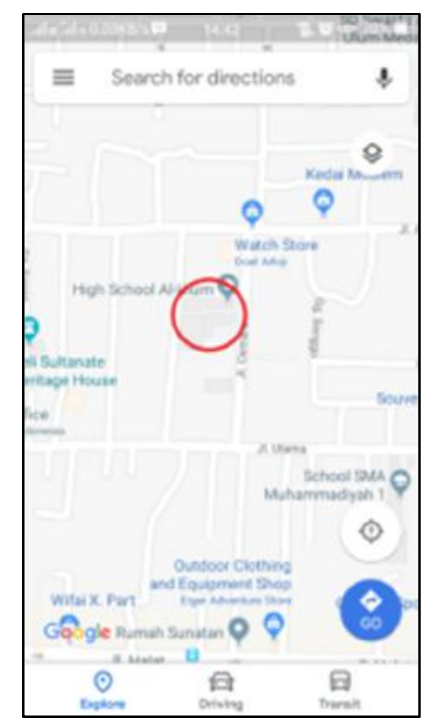

Gambar 15 Lokasi Sekolah

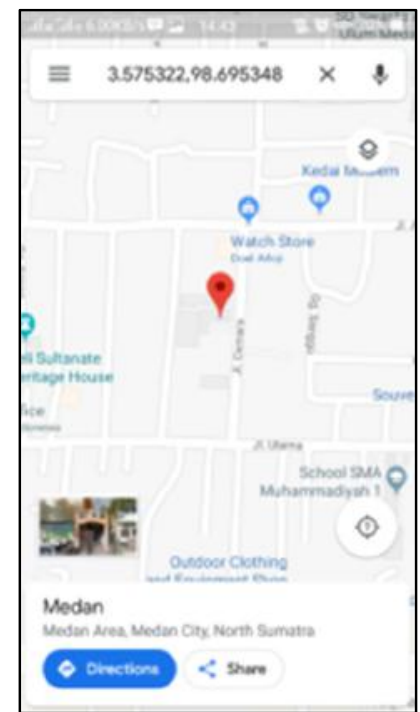

Gambar 18 Pengujian No. 3

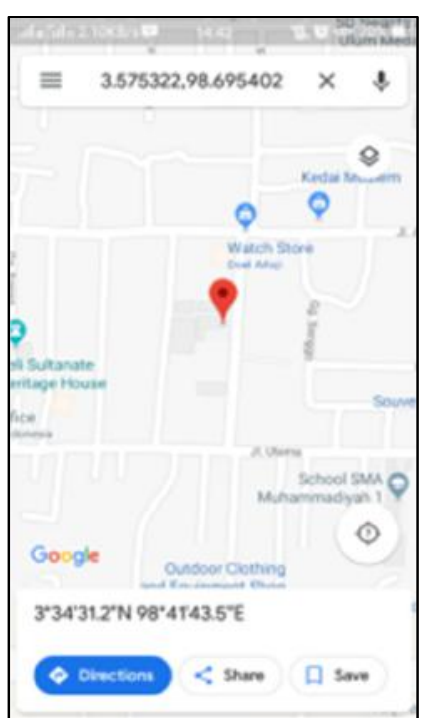

Gambar 16 Pengujian No. 1

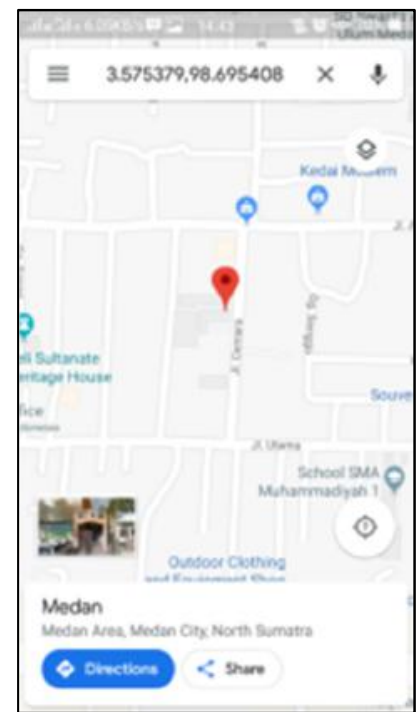

Gambar 19 Pengujian No. 4

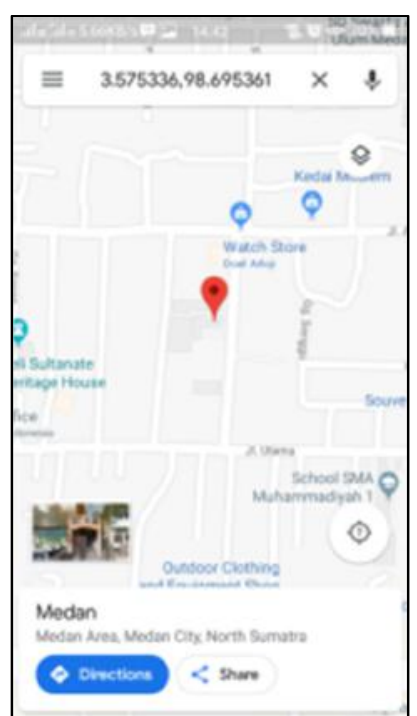

Gambar 17 Pengujian No. 2

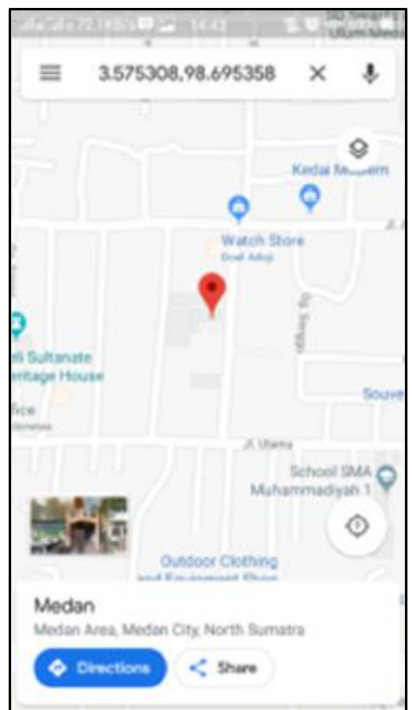

Gambar 20 Pengujian No. 5 


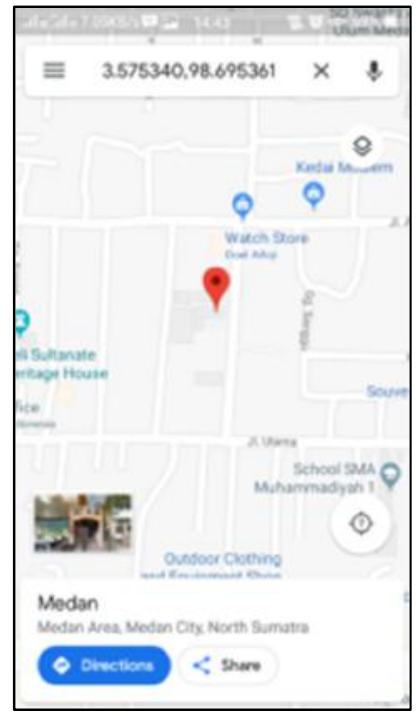

Gambar 21 Pengujian No. 6

Kemudian hasil pengujian pada waktu diatas 14:00 WIB dengan asumsi bahwa anak berada di luar lingkungan sekolah menuju rumahnya.

\section{Tabel 2 Hasil Pengujian Pada Waktu Diatas 14:00 WIB}

\begin{tabular}{|c|c|c|c|}
\hline $\begin{array}{c}\text { No. } \\
\text { pengujian }\end{array}$ & $\begin{array}{c}\text { Waktu (dalam } \\
\text { WIB) }\end{array}$ & $\begin{array}{c}\text { Data lokasi yang diperoleh } \\
\text { dari alat pelacak (latitude, } \\
\text { longitude) }\end{array}$ & $\begin{array}{c}\text { Keterangan (apakah lokasi anak } \\
\text { berada di luar lingkungan sekolah ? } \\
\text { ya/tidak) }\end{array}$ \\
\hline 1 & $14: 00-14: 30$ & $3.574163,98.695515$ & Ya \\
\hline 2 & $14: 30-15: 00$ & $3.572371,98.695975$ & Ya \\
\hline 3 & $15: 00-15: 30$ & $3.575199,98.708137$ & Ya \\
\hline 4 & $15: 30-16: 00$ & $3.576012,98.708489$ & Ya \\
\hline
\end{tabular}

Dari data latitude dan longitude pada tabel 2 diatas jika dimasukkan kedalam aplikasi google maps maka akan tampak bahwa posisi anak masih dalam lokasi di luar lingkungan sekolah. Seperti pada kumpulan beberapa gambar berikut ini.

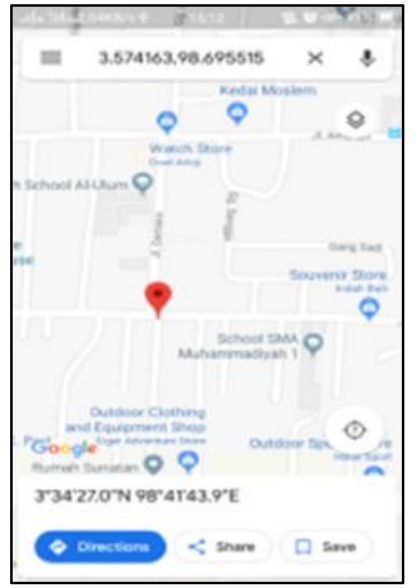

Gambar 22 Pengujian No. 1

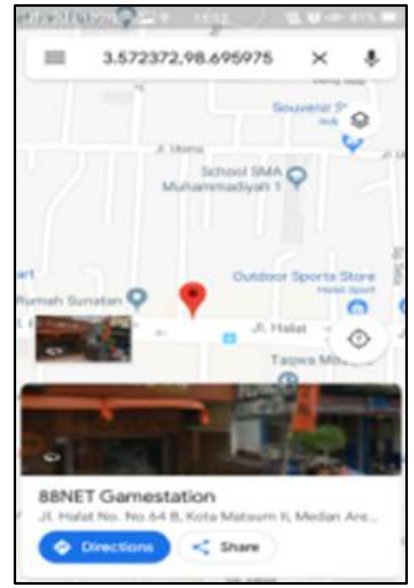

Gambar 23 Pengujian No. 2

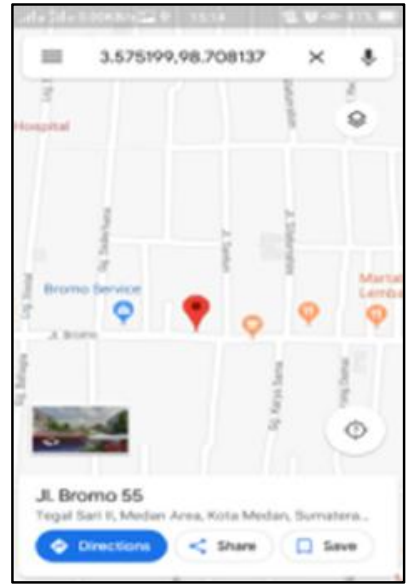

Gambar 24 Pengujian No. 3 


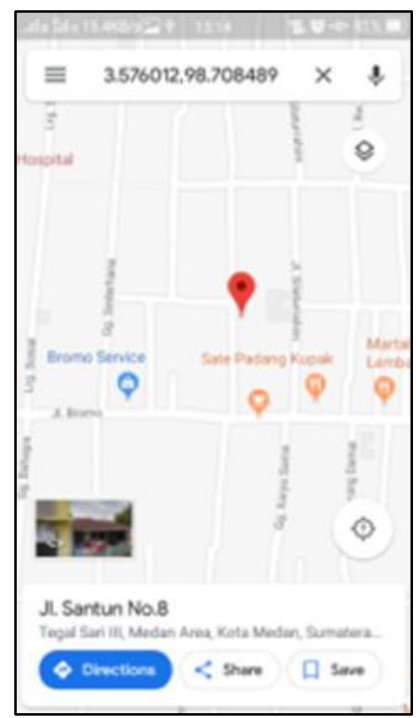

Gambar 25 Pengujian No. 4

dari gambar 25 dapat dilihat bahwa posisi lokasi anak berada di luar lingkungan sekolah dan sudah berada rumahnya. Dari keseluruhan data pengujian dapat dilihat informasi posisi lokasi anak dapat dilacak dengan mudah. Dan semua asumsi baik anak berada di dalam lingkungan sekolah dan diluar lingkungan sekolah pada waktu tertentu dapat dipantau dengan baik. Dari hasil pembahasan dapat dibandingkan dengan penelitian sebelumnya yang telah dijelaskan pada bab pendahuluan bahwa implementasi dari perangkat keras maupun perangkat lunak dapat digunakan dengan baik untuk pelacakan lokasi anak oleh orang tua. Sehingga dapat mengantisipasi tindakan penculikan anak di lingkungan sekolah maupun diluar lingkungan sekolah.

\section{KESIMPULAN}

lain :

Berdasarkan hasil pembahasan penelitian dapat diberikan beberapa kesimpulan, antara

1) Hasil perancangan alat pelacak baik perangkat keras dan perangkat lunak dapat bekerja dengan baik.

2) Data lokasi dari alat pelacak berdasarkan posisi latitude dan longitude dapat diproses menjadi informasi yang akurat.

3) Alat pelacak lokasi dapat digunakan dengan mudah baik bagi orang tua maupun anak mereka sehingga dapat mengantisipasi tindakan penculikan anak.

\section{SARAN}

Hasil perancangan alat pelacak lokasi ini masih terdapat kekurangan yaitu sumber arus yang terbatas dengan waktu karena masih menggunakan batere sehingga diperlukan perbaikan pada komponen sumber arus. Kemudian alat ini masih mengolah data dan informasi lokasi berdasarkan posisi latitude dan longitude yang belum terekam kedalam database oleh karena itu diperlukan penyediaan ruang penyimpanan yang besar. Dengan tersedianya rekaman data lokasi dalam database maka dimungkinkan untuk menerapkan beberapa metode lain seperti data 
mining, machine learning atau big data untuk menganalisis pengenalan pola pergerakan lokasi dari satu tempat ke tempat yang lain serta memprediksi kegiatan apa yang akan dilakukan oleh anak pada waktu - waktu tertentu.

\section{DAFTAR PUSTAKA}

[1] Setiawan, D. 2017. Cegah Insiden Penculikan Anak, KPAI Minta Perhatian Orang Tua. http://www.kpai.go.id/berita/cegah-insiden-penculikan-anak-kpai-minta-perhatian-orangtua, diakses tanggal 12 Oktober 2017.

[2] Satria, A.E, Brahmana, K. 2013. Pemakaian Modul GPS LR9540 (NMEA) Untuk Mendapatkan Data Waktu Universal Berbasis Mikrokontroller Atmega8535. Saintia Fisika Vol 6 No 1 Tahun 2013.

[3] Sidik, M.A.B, et al. 2015. Arduino-Uno Based Mobile Data Logger with GPS Feature. TELKOMNIKA, Vol.13, No.1, March 2015, pp. 250-259.

[4] Anas, N, Nurussa'adah, Nanang S. 2014. Aplikasi GPS Pada Kereta Api Sebagai Sarana Informasi Bagi Penumpang Berbasis Atmega. Jurnal Mahasiswa TEUB Vol 1 No 6 Tahun 2014.

[5]Fadjrimiratno, M.F, et al. 2015. Deteksi Otomatis Pencurian Pada Pengangkutan BBM Berbasis Modul GPRS, GPS, Dan Mikrokontroler. TRANSMISI Vol 17 No 32015 Hal 108112.

[6] Candra H, et al. 2015. Design And Test Performance System Automatic Control On Drip Irrigation Using Microcontroller Arduino Mega. Jurnal Teknik Pertanian Lampung Vol. 4, No. 4: 235-244.

[7] Yan, H. H, Rahayu, Y. 2014. Design and Development of Gas Leakage Monitoring System Using Arduino And ZigBee. Proceeding Of The Electrical Engineering Computer Science And Informatics Vol 1 hal 207-212.

[8] Kurniawan, N, Benino, N, Sinuraya, E.W. 2015. Membaca Dan Mengirim Data Melalui Protokol HTTP Menggunakan Library Webclient Arduino. TRANSMISI Vol 17 No 2 Tahun 2015.

[9]Franata, R, Oktafri, Tusi, A. 2015. Design Of Automatic Drip Irrigation Based On Change Of Soil Water Content Using Arduino Nano Microcontroller. Jurnal Teknik Pertanian Lampung Vol 4 No 1 : 19-26.

[10] Putri, H.Y.A, Tusi, A, Lanya, B. 2015. Design Of Micro Climate Data Acquisition System Based Microcontroller Arduino On Green House. Jurnal Teknik Pertanian Lampung Vol. 4, No. 1: 57-64.

[11] Musyafa, M.A, Rasmana, S.T, Susanto, P. 2015. Rancang Bangun Sistem Prabayar Pada PDAM Berbasis Arduino UNO R3. JCONES Vol. 4, No. 1 (2015) 01-06. 